\title{
PASTURE PLANT IDENTIFICATION USING ENZYME ELECTROPHORESIS
}

P. M. Sanders and D. J. Barker

Grasslands Division, DSIR, Palmerston North

\section{Abstract}

Plant enzymes can be electrophoretically separated and identified by specific staining. Resulting banding patterns can enable the identification of enzyme genotypes for individual plants. The ability to identify banding patterns for particular enzymes has a number of applications. Three examples are documented here: i) Identifying clones, e.g. Tritolium hybrids, ii) Identifying hybrid progeny, e.g. subterranean clover (T. subterraneum L.). and iii) Distinguishing cultivars on the basis of population allele frequency, e.g. perennial ryegrass (Lolium perenne L.) cuttivars Ellett, Grasslands Nui and Grasslands Ruanui.

Keywords: Isozymes, pasture plants, enzyme genotypes.

\section{INTRODUCTION}

Plant genotypes are usually distinguished on the basis of morphological criteria, such as plant size, yield and flowering dates, which are the combined effects of many genes. This involves detailed observations on spaced plants. However, biochemical methods have recently been applied to the analysis of agricultural plants.

Electrophoresis is the separation of charged molecules in an electric field. Proteins are charged molecules (+ve, - ve), thus electrophoresis allows the separation of cellular protein components. Staining the total protein present produces a pattern consisting of a large number of bands (e.g. Forde \& Gardiner this proceedings). Enzymes are proteins with biological activity and can be identified by selective staining. Enzyme stains result in a small number of specific bands. Isozymes are defined as different enzymes which have the same biological activity, and allozymes are isozymes represented by alleles from the same gene locus. Allozymes with contributions from more than two alleles are said to be polymorphic. Most plant enzyme alleles are condominant, which enables the identification of heterozy gotes $(A B)$ as easily as homozygotes ( $A A, A B)$. The identification of different allozyme banding patterns in conjunction with crossing experiments allows the characterisation of enzyme genotypes for individual plants.

For plant identification purposes it is important that the enzymes under study are stable throughout the growth of the plant, and are not influenced by the environment (Nielsen 1985). In this paper we give examples of three uses for the identification of plant enzymes by electrophoresis;

i) Clonal identification - recognising constant genotypes.

ii) Identifying hybrids $\boldsymbol{m}$ distinguishing progeny in crossing experiments.

iii) Distinguishing cultivars - overall population identification.

These examples are discussed in the context of overseas work in this field.

\section{METHODS AND MATERIALS}

Fresh leaf tissue $(0.15 \mathrm{~g})$ from individual plants was ground in $0.5 \mathrm{ml}$ of extraction buffer (0.5 M Tris, pH7.2, $10 \%$ sucrose, $0.01 \mathrm{ml}$ per $50 \mathrm{ml} \beta$-mercaploethanol), centrifuged $(10,000$ $\mathrm{g}, 10 \mathrm{~min})$ to remove debris and $15 \mu \mathrm{l}$ of supematant was loaded into gels. Vertical polyacrylamide slab $(0.75 \mathrm{~mm})$ gels were prepared and run in Biorad Box Kits (Model No. 220). A 5 or $7.5 \%$ acrylamide running gel (pH8.3, $200 \mathrm{mV}$ ) with stacking gel $(\mathrm{pH} 6.9,50 \mathrm{mV})$ gave the best result. A tris/glycine buffer system (Tanksley and Orton 1983) was utilised with Trifolium spp, and a tris-citrate/lithium-borate buffer system with perennial ryegrass (Lolium perenne L.) (Hayward and McAdam 1977).

Staining of enzyme activity was according to Collins et al. (1984) for isocitrate dehydrogenase (ISOC.DH) and dipeptidase (DIP), and Hayward and MCAdam (1977) for phosphoglucoisomerase (PGI). 


\section{IDENTIFYING CLONES}

Since plants of the same genotype will have the same isozyme banding patterns, clones can therefore be identified. Apomictic reproduction, micro-propagation in tissue culture, propagation by cuttings and tillering all result in clonal material. Different hybrid plant genotypes would reproducprobably have different banding patterns.

In 1978 interspecific hybrids between Trifolium ambiguum (Caucasian clover) x $T$ repens (white clover) were obtained by embryo rescue (Williams 1978). The number of different genotypes present was not known. Although there were five numbered series of plants, it was suspected they were only replicates (clones). Extracts of plants from the five $T$. ambiguum $\times T$. repens hybrid series and from five progeny of a backcross with $T$. repens were run and stained for PGI. Figure 1 shows the banding patterns for the PGI-2 locus. All hybrid plants showed the same pattern at the PGI-2 locus. It was concluded they were likely to be replicates (clones)-of the same original hybrid plant. The pattern of the backcross progeny shows the variation seen in outcrossed plants.

\section{(1)}

(2)

GENOTYPES

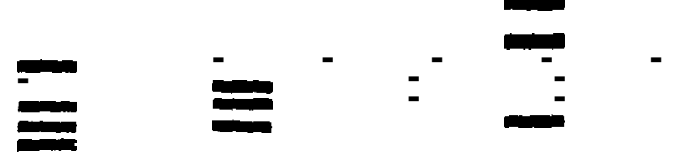

Figure 1: Diagram of phosphoglucoisomerase loci-2 banding patterns for (1) T. ambiguum $\times$ T. repens ( $F 1$ ) hybrtd plants all show the same banding pattern, (2) Five F2 progeny of $F 1 \times T$. repens - show variation in banding patterns

\section{IDENTIFYING HYBRID PROGENY}

Trifolium subterranean L. (subterranean clover) is an inbreeding pasture species of importance in dry environments. Self progeny are the same genotype and therefore have the same enzyme banding pattern as the parent plant. Collins et a/. (1984) described the isozyme patterns of 22 Australian cultivars for 15 enzyme systems using germinated embryos and starch gels.

At Grasslands Division the subterranean clover cultivars Tallarook (female) and Nangeela (male) have been hand crossed. The inbreeding nature of the plants creates a difficulty in distinguishing between the desired hybrid progeny and contaminating Tallarook self progeny. Knowledge of the ISOC.DH and DIP enzyme differences between the two cultivars allowed differentiation between self and hybrid progeny (Figure 2). Hybrid progeny show expression of paternal alleles, this may be in replacement of maternal alleles (ISOC.DH) or in conjunction with maternal alleles (DIP), allowing early identification for further agronomic trials.

A similar use has been described for confirming identification of $T$. ambiguum $\times T$ repens hybrids (see earlier) with isozymes of peroxidase, esterase and acid phosphatase (Williams 1978).

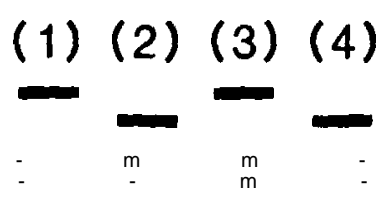

ISOCITRATE DEHYDROGENASE
(1) (2) (3) (4)

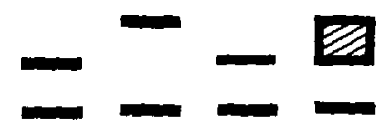

DIPEPTIDASE

Figure 2: Leaf isozyme banding patterns for the identification of hybrids after hand crossing two subterranean clover cultivars. (1) Tallarook- as female, (2) Nangeela- as male, (3) self progeny of Tallarook, (4) hybrids show the expression of paternal Nangeela genes. 


\section{DISTINGUISHING CULTIVARS}

The identification of cultivars of inbreeding species with isozymes is straightforward (eg: T. subterranean see earlier, Poa pratensis Wu et al. 1984). inbreeding species comprise mainly homozygous (AA) plants and are often monomorhic (only one form based on one allele). In principle, an inbreeding cultivar could be distinguished by analysing a single plant though varietal polymorphism (distinct forms based on different alleles) can occur.

In outcrossing species, polymorphism is prevalent with populations consisting of both homozygotes $(A A, B B)$ and heterozygotes $(A B)$. Some individuals from two cultivars of the same species will almost certainly have the same enzyme genotypes. To characterise cultivars of outbreeding species analysis of a considerable number of individual plants is required, to determine the overall population frequency. Frequencies of plant enzyme genotypes and ultimately enzyme alleles can be specific and diagnostic for cultivars and ecotypes.

We have analysed four populations of perennial ryegrass; three New Zealand cultivars, Grasslands Nui (Grasslands Division accession number A4343), Grasslands Ruanui (A4659), Ellett (A4730) and a resident population from a 40-year-old pasture at Rawhiti, central Wairarapa. Extracts from 100 plants of each population were individually stained for PGI. Crossing experiments and progeny analysis have been carried out (Hayward and McAdam 1977) which enable the identification of enzyme genotypes from banding patterns for the PGI-2 locus, as shown in Figure 3. PGI-2 is dimeric, the functional enzyme has two protein subunits which can be coded for by either allele. Heterozygotes show three bands in stained gels (Figure 3), with the heterodimer in the intermediate position, The population genotype and allele frequencies show (Table 1), identifiable differences between the four populations.

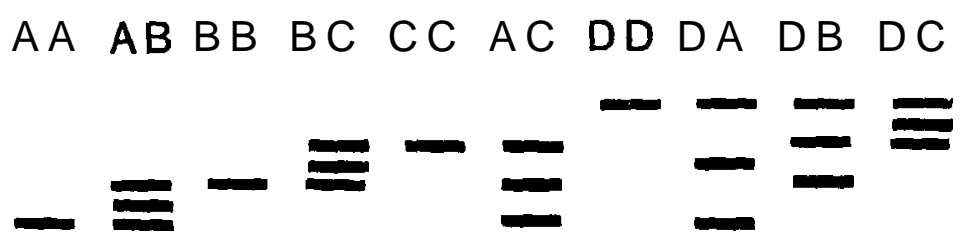

Figure 3: Diagram of the allozyme banding patterns for the 10 possible genotypes of PGI-2 found in the perennial ryegrass populations studied.

Table 1: Observed genotype and allele frquencies for the phosphoglucolsomerase-2 loci in the perennial ryegrass populations studied ( $\mathrm{n}=100$ plants)

GENOTYPE FREQUENCY ALLELE FREQUENCY

\begin{tabular}{lllllllllllllllllll} 
& AA & AB & BB & BC & CC & AC & DD & DA & DB & DC & A & B & C & D \\
\hline Grasslands Ruanui(A4659) & 2 & 12 & 18 & 40 & 17 & 11 & 0 & 0 & 0 & 0 & .135 & .440 & .425 & 0 \\
Grasslands Nui (A4343) & 29 & 21 & 2 & 9 & 3 & 37 & 0 & 0 & 0 & 0 & .580 & .165 &, 255 & 0 \\
Ellett (A4730) & 13 & 27 & 19 & 15 & 4 & 19 & 0 & 2 & 0 & 1 & .370 & .400 &, 215 &, 015 \\
Rawhiti Resident population & 5.2711 & 27 & 917 & 0 & 2 & 1 & 1 & .280 & .385 & .315 &, 020 \\
\hline
\end{tabular}

\section{DISCUSSION}

Isozyme analysis is a non-destructive method requiring a small amount of leaf tissue, which can be collected directly from field grown plants. In conjunction with crossing experiments it allows identification of specific enzyme genotypes through the ability to recognise individual enzyme alleles (perennial ryegrass example). For some applications banding pattern identification may be all that is required (Trifolium clone example).

Clonal identification by isozyme analysis has particular uses in ecological and field based studies other than those mentioned for discriminating inbreeding cultivars. Harris et al. (1979) observed the spread by stolons of perennial ryegrass using esterase genotypes, In a larger study, McNeilly and Roose (1984) utilised four polymorphic loci (1080 potentially identifiable enzyme genotypes) to map the distribution of perennial ryegrass clones and genotypes in lo-year-old swards (under different managements) and in 40-year-old pasture. 
The number of distinct isozyme genotypes varied with sward type, with 36-43 in the lo-year-old swards (per $0.25 \mathrm{~m}^{2}$ ) and 5 in the 40-year-old pasture (per $0.25 \mathrm{~m}^{2}$ ).

Although one major impetus behind the adoption of isozyme analysis to pasture plants has been the interest in finding a quantitative and analytical means to identify cultivars for registration of plant variety rights (Hayward and McAdam 1977, Gilliland et al. 1982, Nielsen 1985), the electrophoretic analysis of seed protein is quicker and perhaps more suitable (Gardiner et al. 1986). This method gives a total view of the cultivar population through analysis of a bulk seed sample. The procedure is particularly suited to qualitative analyses of contamination problems in seed storage and multiplication. However, the PGI-2 allele frequencies of 23 cultivars of Lolium perenne registered in the U.K. have been quantified (Gilliland et al. 1982), and their potential for registration of plant variety rights assessed. The authors and Neilsen (1985) concluded that the technique was a powerful means of cultivar identification.

Using isozyme banding patterns, field studies were able to consider natural selection in pure swards of one cultivar, in perennial ryegrass under frequent cutting (Hayward et al. 1978) and in Yorkshire fog (Holcus lanatus L.) under sheep grazing (Clements and Easton 1973). Discrimination of pasture plant varieties of the same species by allozyme genotype identification allows scope for intraspecific competition studies under field conditions. This is of particular interest in outbreeding pasture plants where quantifying the contribution made by cultivars within a mixed sward has previously not been possible. A statistical approach for the analysis of sward mixtures of two populations of perennial ryegrass is presented by Kennedy et al. (1985). The procedure enables an assessment of the contribution of each population to the mixed sward, based on the allozyme allele and genotype frequencies of the individual pure populations. The proportion of each population present influences the mixed sward allele frequency, so the level of each can be determined. This procedure could have potential in analysis of pasture plant introduction and cultivar evaluation trials, enabling a study of the performance of pasture plant varities under field conditions.

\section{References}

Clements R.J., Easton H.S. 1973. Genetic shifts in a Yorkshire fog population grazed by sheep. Proceedings NZ Grassland Association 35: 268-277.

Collins W.J.. Rossiter R.C., Haynes Y., Brown A.H.D., Marshall D.R. 1984. Identification of subterranean clover cultivars and their genetic relationships by isozyme analysis. Australian Journal of Agricultural Research 35: 268-277.

Gardinsr S.E., Forde M.B., Slack C.R. 1966. Grass cultivar identification by sodium dodecylsulphate polyacrylamide gel electrophoresis. NZ Journal of Agriculture Research 29: 193-206.

Gilliland T.J.. Camlin M.S., Wright C.E. 1962. Evaluation of phosphoglucoisomerase allozyme electrophoresis for the identification and registration of cultivars of perennial ryegrass (Lolium perenne). Seed Science and Technology 10: 415.430.

Harris W.. Pandey K.K., Gray Y.S., Couchman P.K. 1979. Observations on the spread of perennial ryegrass by stolons in a lawn. NZ Journal of Agricultural Research 22:61-68.

Hayward M.D., McAdam N.J. 1977. Isozyme polymorphism as a measure of distinctiveness and stability in cultivars of Lolium perenne. Zeitschrift Pflanzenzüchtg 79: 59-68.

Hayward M.D., Gottlieb L.D., McAdam N.J. 1970. Survival of allozyme variants in wards of Lolium perenne L. Zeitschrift Pflanzenzüchtg 81: 228-234.

Kennedy S.J., Gardiner S.J., Gilliland T.J., Camlin M.S. 1965. The use of electrophoretic techniques to distinguish perennial ryegrass cultivars sown in mixtures. Journal of Agricultural Science, Cambridge 104: 1-9.

McNeilly T., Roose M.L. 1984. The distribution of perennial ryegrass genotypes in swards. New Phytologist 98: 503-513.

Nielsen G. 1985. The use of isozymes as probes to identify and label plant varieties and cultivars. Isozymes: Current Topics in Biological and Medical Research 72: 1-32.

Tanksley SD., Orton T.J. 1993. Eds. "Isozymes in Plant Genetics and Breeding, Part A and B". publ. Elsevier, Amsterdam.

Williams, E. 1978. A hybrid between Triblium repens and T. ambiguum obtained with the aid of embryo culture. NZ Journal of Botany 16: 499-506.

Wu L., Harivandi H., Harding J.A.. Davis W.B. 1984. Identification of Kentucky bluegrass cultivars with esterase and phosphoglucomutase isoenzyme markers. Crop Science 24: 762-768. 